\title{
ANTIBACTERIAL ACTIVITY OF LIANOID AND ARBOREAL SPECIES OF SCHEFFLERA FROM SOUTHERN INDIA
}

\author{
DEEPA RAGHAVENDRA HEBBAR ${ }^{1}$, MONNANDA SOMAIAH NALINI ${ }^{2 *}$ \\ ${ }^{1}$ Department of Botany, Maharani's Science College for Women, Mysore, Karnataka, India. ${ }^{2}$ Department of Botany, University of Mysore, \\ Mysore, Karnataka, India. Email: nmsomaiah@gmail.com
}

Received: 21 February 2020, Revised and Accepted: 21 March 2020

\section{ABSTRACT}

Objective: The genus Schefflera belongs to the family Araliaceae. The secondary metabolites of Schefflera include triterpene glycosides, oleanolic acid, and benzyl glycosides with proven biological activities. The objective of this study was to determine the antibacterial potentials of lianoid and arboreal Schefflera spp., from southern India.

Methods: Schefflera venulosa, Schefflera stellata, and Schefflera racemosa were collected from the natural forests of Kodagu and Mysore regions of southern Karnataka. The plant parts such as stem bark, leaves, and inflorescence were dried, powdered and known quantity was subjected to Soxhlet extraction based on the solvent polarity. The solvent extracts from each of the species were subjected to preliminary antibacterial screening against five test bacterial strains, namely, Staphylococcus aureus, Streptococcus pyogenes, Bacillus subtilis, Enterobacter aerogenes, and Klebsiella pneumoniae by agar disc diffusion method and the inhibition zones were measured. The minimum inhibitory concentrations (MIC's) were calculated for the positive extracts and represented.

Results: Of the 30 solvent extracts tested, six solvent extracts showed antibacterial activity. The ethanol and ethyl acetate solvent extracts of all three plants showed positive results for antibacterial activity. The zone of inhibition against the bacterial test pathogens ranged from $6.00 \pm 0.00$ to $15.00 \pm 0.00 \mathrm{~mm}$ against B. subtilis, E. aerogenes, S. pyogenes, and K. pneumoniae. The highest zones of inhibition were observed for $S$. racemosa leaf ethanol extract against B. subtilis, E. aerogenes, and $S$. pyogenes $(10.00 \mathrm{~mm}$ to $15.00 \pm 0.00 \mathrm{~mm})$. The MIC values of the positive extracts were $5.0 \mathrm{mg} / \mathrm{ml}$ in the leaf, flower ethanol, and stem bark ethyl acetate extracts of $S$. venulosa, leaf ethyl acetate and ethanol extracts of $S$. stellata and the leaf ethanol extract from $S$. racemosa, respectively.

Conclusion: Schefflera spp. from southern India possesses antibacterial potentials, which can be exploited pharmaceutically for potential health benefits against bacterial infections.

Keywords: Schefflera, Antibacterial, Minimum inhibitory concentrations, Phytochemicals, Solvent extracts.

(c) 2020 The Authors. Published by Innovare Academic Sciences Pvt Ltd. This is an open access article under the CC BY license (http://creativecommons. org/licenses/by/4. 0/) DOI: http://dx.doi.org/10.22159/ajpcr.2020.v13i6.37222

\section{INTRODUCTION}

World Health Organization has warned about the multidrug-resistant bacteria that are emerging worldwide as a huge challenge to healthcare as antibiotics may lose their power to cure diseases [1]. Enterobacter aerogenes and Klebsiella pneumoniae are Gram-negative bacteria responsible for a wide variety of diseases in humans. E. aerogenes is widely distributed in the soil, water, dairy products, and in the intestine of animals as well as humans. Antimicrobial resistance has been found in pathogenic and non-pathogenic strains of E. aerogenes [2]. $K$. pneumoniae is an important pathogen in nosocomial infections, which have been well documented in the US and India [3]. They are found to be the primary cause of respiratory tract infections and are also commonly involved in acute pyelonephritis in pregnant women with urinary tract abnormalities [4]. Staphylococcus aureus and Streptococcus pyogenes are Gram-positive, non-spore forming facultative anaerobic bacteria that are able to invade through the broken skin or mucous membrane. Infections caused by $S$. pyogenes include pharyngitis, localized skin infections, rheumatic heart disease, rheumatic fever, and streptococcal toxic shock syndrome [5], while $S$. aureus causes skin lesions such as boils, furuncles, and more serious infections such as pneumonia, phlebitis, meningitis, and urinary tract infections. Bacillus subtilis is a Gram-positive, mesophylic, endosporeforming saprophyte, which has been listed among foodborne pathogens involved in the outbreaks from contaminated food and water. These organisms have been recognized with the ability to develop resistance to antibiotics [6].
Historically, plants have provided a source of inspiration for novel drug compounds, as plant-derived medicines have made large contributions to human health and well-being [7]. Approximately 25-50\% of current pharmaceuticals are derived from plants. Several studies indicate that medicinal plants contain chemical compounds such as peptides, unsaturated long-chain fatty acids, aldehydes, alkaloids, essential oils, tannins, flavonoids, saponins, glycosides, and phenols as water or ethanol-soluble compounds which are significant in therapeutic applications against the pathogens such as bacteria, fungi, and viruses [8]. The antimicrobial properties of plant extracts have been reported with increasing frequency from different parts of the world [9-11]. Several works have demonstrated in laboratory trials that different plant tissues such as roots, leaves, seeds, and flowers possess inhibitory properties against bacteria, fungi, and insects [12].

Schefflera comprises lianoids or arboreal genera in the family Araliaceae [13]. Schefflera venulosa (W.\&A.) Harms., commonly called Schefflera vine, is a large climbing shrub with digitate compound leaves. The phytoconstituents $S$. venulosa are mainly caffeoyl acids, quercetin glycoside, and oleanolic acid glycoside which help in blood circulation and prevents cardiac and cerebral vascular diseases [14]. Schefflera stellata is a small tree distributed in peninsular India and Sri Lanka [15]. Ethnomedicinal uses of $S$. stellata revealed that it is used to cure neurological weakness [16] and a belief that the bark ash is used to control evil spirits [17]. The antimicrobial activity of $S$. stellata from volatile oils of root, stem, and leaves was determined [18]. Schefflera racemosa is a medium-sized tree with compound leaves and flowers 
in lateral panicled racemes and is endemic to the Western Ghats. The phytochemicals, phenolic content, and antioxidant activities in the plant parts of $S$. venulosa, $S$. stellata, and $S$. racemosa are reported $[19,20]$. This study explores the antibacterial activity of solvent extracts from three Schefflera species against Gram-positive and Gram-negative bacteria.

\section{METHODS}

\section{Collection of plant material}

Schefflera species, namely, S. venulosa (W.\&A.) Harms. and S. racemosa (Wight) Harms., were collected from the natural forests of Kodagu (N12 $20^{\prime} 14.97^{\prime \prime}$ and E75 $48^{\prime} 24.86^{\prime \prime}$ ), in the Western Ghats, while $S$. stellata (Gaertn.) Harms. was collected from Chamundi Hills (N 12 ${ }^{\circ} 16^{\prime} 21.1368^{\prime \prime}$ and E 76 $40^{\circ} 14.3364^{\prime \prime}$ ) of Mysore, Karnataka, during May to September 2011 (Fig. 1). Each species considered for the study was photographed. The plant part such as leaves, stem bark, and inflorescence was excised with a plier and placed in zip lock polythene bags, labeled, brought to the laboratory, and processed for further use. A herbarium specimen of each plant species was prepared and submitted to the herbarium collection of the Department of Studies in Botany, University of Mysore, Manasagangotri, Mysore.

\section{Preparation of solvent extracts}

The collected plant parts were thoroughly washed to remove dust and debris, and further dried under shade. Drying was completed at $40^{\circ} \mathrm{C}$ in a hot air oven (Neolab, Maag Industries, Mumbai) before blending to remove the water content and powdered. The powdered materials weighing approximately $500 \mathrm{~g}$ were placed in polyethylene zip lock covers for further use. Fifty gram of the powdered material was filled tightly into a thimble and was placed in the extraction tube of the Soxhlet apparatus (Borosilicate glass, Padmashree Scientific ${ }^{\circledR}$ ). Five solvents were used for the extraction based on their polarity, namely, hexane (non-polar), chloroform (non-polar), ethyl acetate (semi-polar), ethanol (polar), and methanol (polar). Three hundred fifty milliliter of each solvent was used for the extraction process. After extraction, the distillate was collected and poured into Petri plates for drying. A similar process for other solvents was carried out. The extracts were scraped and transferred into pre-weighed Eppendorf tubes, labeled, and stored for further use.

\section{Test strains and culture media}

Strains of bacteria and fungi were obtained from MTCC (Microbial Type Culture Collection, Chandigarh, India). The antimicrobial activity of 30

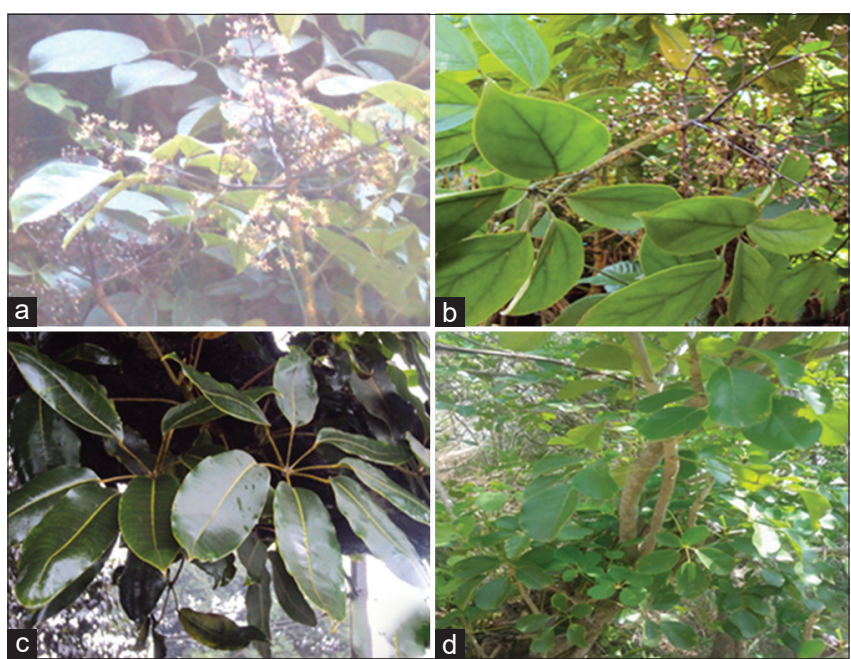

Fig. 1: Habit of Schefflera species collected from southern India. (a) Schefflera venulosa (W.\&A.) Harms. habit with digitate leaves and panicle inflorescence. (b) A close up of $S$. venulosa leaves with prominent main nerves. (c) Schefflera racemosa (Wight) Harms. with digitate leaflets collected from the natural forests of Kodagu, Western Ghats. (d) Schefflera stellata (Gaertn.) Harms., with obovate, rounded leaflets collected from Chamundi Hills, Mysore extracts against B. subtilis (MTCC 121), S. aureus (MTCC 7443), S. pyogenes (MTCC 1925), E. aerogenes (MTCC 7325), and K. pneumoniae (MTCC 7407) were studied. The bacteria were grown in Mueller-Hinton Agar (MHA) (Merck) and Trypticase Soya Broth (Merck). The concentrations of bacterial suspensions were adjusted to $10^{8}$ cells $/ \mathrm{ml}$.

\section{Antibacterial assay}

Sensitivity testing of various solvent extracts was done using the agar well diffusion method as well as the agar disc diffusion method, as previously described with minor modifications [21]. Approximately $20 \mathrm{ml}$ of molten, sterilized MHA media were poured into sterilized Petri plates and was allowed to solidify. A hundred microliter of the inoculum was used to prepare the bacterial lawn. In the agar well diffusion method, wells were bored into agar medium using sterile $6 \mathrm{~mm}$ cork borer. Ten microliter $(100 \mathrm{mg} / \mathrm{ml})$ of the plant extract was aseptically added to the well. In the agar disc diffusion method, $10 \mu \mathrm{l}$ $(100 \mathrm{mg} / \mathrm{ml})$ of the plant extract was infused onto a sterile paper disc. Positive control (Ciprofloxacin $10 \mu \mathrm{l}, 1 \mathrm{mg} / \mathrm{ml}$ ) and negative control (respective solvent) $(10 \mu \mathrm{l}, 1 \mathrm{mg} / \mathrm{ml})$ were maintained for both well diffusion and disc diffusion methods. The plates were then allowed to stand for $20 \mathrm{~min}$ to allow proper diffusion of the solution into the medium before incubation. They were then incubated at $28^{\circ} \mathrm{C}$ for $24 \mathrm{~h}$. The antibacterial activity was evaluated by measuring the zones of inhibition against the test organisms. The experiment was replicated 2 times and zone of inhibition was recorded as mean \pm SD.

\section{Determination of minimum inhibitory concentration (MIC)}

MIC was determined by following the Clinical and Laboratory Standards Institute guidelines [22]. Cell suspension prepared from bacterial cultures grown on Trypticase Soya Broth adjusted to $1-2 \times 10^{5}$ cells $/ \mathrm{ml}$ using turbidity equivalent to a 0.5 McFarland standard. Ciprofloxacin, 2-128 $\mu \mathrm{g} / \mathrm{ml}$ (Twofold dilutions) in Mueller-Hinton Broth/Tryptone broth were used as standard. Mueller-Hinton broth inoculated with culture and without drug was used as control. Ninety microliter of the solvent extract of different concentrations was mixed with $10 \mu \mathrm{l}$ of inoculum in a 96 - well microtiter plate (Tarsons, Mumbai) in triplicate. For the control, $90 \mu \mathrm{l}$ Mueller-Hinton Broth without solvent extract was mixed with $10 \mu \mathrm{l}$ of inoculum. The treated bacterial cultures were incubated at $25^{\circ} \mathrm{C}$ and $35^{\circ} \mathrm{C}$, respectively. The bacterial test plates were observed after $24-48 \mathrm{~h}$ and $\mathrm{OD}$ at $600 \mathrm{~nm}$ were measure in Tecan plate reader (Tarsons, Mumbai). The MIC was determined as the minimum concentration of drug giving $50 \%$ inhibition of OD as compared with control using the formula

$$
\left.\% \text { Inhibition }=\left(\mathrm{Abs}_{\text {control }}-\mathrm{Abs}_{\text {sample }}\right) / \mathrm{Abs}_{\text {control }}\right) \times 100
$$

\section{Statistical analysis}

All the experiments were done in triplicates. Statistical analysis was done using SPSS program (version 16.0). One-way ANOVA and post hoc tests were conducted and probability (p) value $<0.05$ was considered as significantly different

\section{RESULTS}

The antibacterial activities of various solvent extracts on the test organisms were assessed in terms of diameters of inhibition zones and are represented in Tables 1-3. The zones of inhibition (clear zones on agar) for all the organisms tested were measured in $\mathrm{mm}$. Of the 30 solvent extracts tested, six solvent extracts showed antibacterial activity. The ethyl acetate, ethanol, and methanol solvent extracts of all three plants showed good results, while the non-polar extracts did not show positive results for antibacterial activity. The ethanol leaf and flower extract of $S$. venulosa showed an inhibition zone of $6.00 \pm 0.00 \mathrm{~mm}$ and $9.00 \pm 0.25 \mathrm{~mm}$, respectively, against $B$. subtilis, while the ethyl acetate stem bark extract showed an inhibition zone of $8.00 \pm 0.50 \mathrm{~mm}$ and $8.00 \pm 0.25 \mathrm{~mm}$ against $E$. aerogenes and $K$. pneumoniae, respectively (Table 1). The ethanol leaf extract of $S$. racemosa showed potent antibacterial activity against $B$. subtilis $(10.00 \pm 0.00 \mathrm{~mm}), S$. pyogenes $(13.00 \pm 0.50 \mathrm{~mm})$, and E. aerogenes $(15.00 \pm 0.00 \mathrm{~mm})$ (Table 3$)$. The ethyl acetate and the ethanol leaf extracts of $S$. stellata showed an 
inhibition zone of $10.00 \pm 0.00 \mathrm{~mm}$ and $9.00 \pm 0.50 \mathrm{~mm}$, respectively, against $S$. pyogenes (Table 3 ).

The MIC was also determined for the extracts showing positive results in the antibacterial activity. Even though eleven solvent extracts showed positive results for the antibacterial activity, their MIC was much greater when compared with the MIC of ciprofloxacin which ranged from 0.0012 to $0.0195 \mathrm{mg} / \mathrm{ml}$. Most of the extracts showed MIC values $>10.00 \mathrm{mg} / \mathrm{ml}$ which is not appreciable (Table 4 ).

\section{DISCUSSION}

Infectious diseases resulting from the presence of resistant microbial agents, including bacteria, fungi, and viruses, have become a major healthcare problem in the current century. The solution for antibiotic resistance is the development of new drugs natural sources because of minimal side effects. The healing power in plants is usually due to the presence of secondary metabolites. Plant extracts and large number of phytochemicals exhibited a strong inhibiting effect on a broad spectrum of microorganisms [9].

Table 1: Inhibitory activity of Schefflera venulosa solvent extracts against the test organisms

\begin{tabular}{|c|c|c|c|c|c|}
\hline Extracts $(10 \mu \mathrm{l}, 100 \mathrm{mg} / \mathrm{ml})$ & B. subtilis & S. aureus & S. pyogenes & E. aerogenes & K. pneumonia \\
\hline \multicolumn{6}{|l|}{ Leaf } \\
\hline Hexane & 0.00 & 0.00 & 0.00 & 0.00 & 0.00 \\
\hline Chloroform & 0.00 & 0.00 & 0.00 & 0.00 & 0.00 \\
\hline Ethyl acetate & 0.00 & 0.00 & 0.00 & 0.00 & 0.00 \\
\hline Ethanol & $6.00 \pm 0.00$ & 0.00 & 0.00 & 0.00 & 0.00 \\
\hline Methanol & 0.00 & 0.00 & 0.00 & 0.00 & 0.00 \\
\hline Ciprofloxacin $(10 \mu \mathrm{l}, 1 \mu \mathrm{g} / \mathrm{ml})$ & $40.00 \pm 1.00$ & $32.00 \pm 0.50$ & $40.00 \pm 0.00$ & $40.00 \pm 1.00$ & $30.00 \pm 0.00$ \\
\hline Hexane & 0.00 & 0.00 & 0.00 & 0.00 & 0.00 \\
\hline Chloroform & 0.00 & 0.00 & 0.00 & 0.00 & 0.00 \\
\hline Ethyl acetate & 0.00 & 0.00 & 0.00 & 0.00 & 0.00 \\
\hline Ethanol & $9.00 \pm 0.25$ & 0.00 & 0.00 & 0.00 & 0.00 \\
\hline Methanol & 0.00 & 0.00 & 0.00 & 0.00 & 0.00 \\
\hline Ciprofloxacin $(10 \mu \mathrm{l}, 1 \mu \mathrm{g} / \mathrm{ml})$ & $40.00 \pm 1.00$ & $32.00 \pm 0.50$ & $40.00 \pm 0.00$ & $40.00 \pm 1.00$ & $30.00 \pm 0.00$ \\
\hline \multicolumn{6}{|l|}{ Stem bark } \\
\hline Hexane & 0.00 & 0.00 & 0.00 & 0.00 & 0.00 \\
\hline Ethyl acetate & 0.00 & 0.00 & 0.00 & $8.00 \pm 0.50$ & $8.00 \pm 0.25$ \\
\hline Ethanol & 0.00 & 0.00 & 0.00 & 0.00 & 0.00 \\
\hline Methanol & 0.00 & 0.00 & 0.00 & 0.00 & 0.00 \\
\hline Ciprofloxacin $(10 \mu \mathrm{l}, 1 \mu \mathrm{g} / \mathrm{ml})$ & $40.00 \pm 1.00$ & $32.00 \pm 0.50$ & $40.00 \pm 0.00$ & $40.00 \pm 1.00$ & $30.00 \pm 0.00$ \\
\hline
\end{tabular}

*All the values are expressed as mean \pm standard error of mean $(\mathrm{n}=3)$. B. subtilis: Bacillus subtilis, S. aureus: Staphylococcus aureus, S. pyogenes: Streptococcus pyogenes, E. aerogenes: Enterobacter aerogenes, K. pneumonia: Klebsiella pneumoniae

Table 2: Inhibitory activity of Schefflera racemosa leaf extracts against the test bacterial organisms

\begin{tabular}{lllll}
\hline Extracts $(\mathbf{1 0} \boldsymbol{\mu l} \mathbf{1 0 0} \mathbf{~ m g} / \mathbf{m l})$ & B. subtilis & S. aureus & S. pyogenes & E. aerogenes \\
\hline Hexane & 0.00 & 0.00 & 0.00 & 0.00 \\
Chloroform & 0.00 & 0.00 & 0.00 & 0.00 \\
Ethyl acetate & 0.00 & 0.00 & 0.00 & 0.00 \\
Ethanol & $10.00 \pm 0.00$ & 0.00 & $13.00 \pm 0.00$ & $15.00 \pm 0.00$ \\
Methanol & 0.00 & 0.00 & 0.00 & 0.00 \\
Ciprofloxacin $(10 \mu \mathrm{l}, 1 \mu \mathrm{g} / \mathrm{ml})$ & $40.00 \pm 1.00$ & $32.00 \pm 0.50$ & $40.00 \pm 0.00$ & $40.00 \pm 1.00$ \\
\hline
\end{tabular}

${ }^{*}$ All the values are expressed as mean \pm standard error of mean $(\mathrm{n}=3)$. B. subtilis: Bacillus subtilis, S. aureus: Staphylococcus aureus, S. pyogenes: Streptococcus pyogenes,

E. aerogenes: Enterobacter aerogenes, K. pneumonia: Klebsiella pneumoniae

Table 3: Inhibitory activity of Schefflera stellata extracts against the test organisms

\begin{tabular}{|c|c|c|c|c|c|}
\hline Extracts $(10 \mu \mathrm{l}, 100 \mathrm{mg} / \mathrm{ml})$ & B. subtilis & S. aureus & S. pyogenes & E. aerogenes & K. pneumoniae \\
\hline \multicolumn{6}{|l|}{ Leaf } \\
\hline Hexane & 0.00 & 0.00 & 0.00 & 0.00 & 0.00 \\
\hline Chloroform & 0.00 & 0.00 & 0.00 & 0.00 & 0.00 \\
\hline Ethyl acetate & 0.00 & 0.00 & $10.00 \pm 0.00$ & 0.00 & 0.00 \\
\hline Ethanol & 0.00 & 0.00 & $9.00 \pm 0.50$ & 0.00 & 0.00 \\
\hline Methanol & 0.00 & 0.00 & 0.00 & 0.00 & 0.00 \\
\hline Ciprofloxacin $(10 \mu \mathrm{l}, 1 \mu \mathrm{g} / \mathrm{ml})$ & $40.00 \pm 1.00$ & $32.00 \pm 0.50$ & $40.00 \pm 0.00$ & $40.00 \pm 1.00$ & $30.00 \pm 0.00$ \\
\hline \multicolumn{6}{|l|}{ Stem bark } \\
\hline Hexane & 0.00 & 0.00 & 0.00 & 0.00 & 0.00 \\
\hline Chloroform & 0.00 & 0.00 & 0.00 & 0.00 & 0.00 \\
\hline Ethyl acetate & 0.00 & 0.00 & 0.00 & 0.00 & 0.00 \\
\hline Ethanol & 0.00 & 0.00 & 0.00 & 0.00 & 0.00 \\
\hline Methanol & 0.00 & 0.00 & 0.00 & 0.00 & 0.00 \\
\hline Ciprofloxacin $(10 \mu \mathrm{l}, 1 \mu \mathrm{g} / \mathrm{ml})$ & $40.00 \pm 1.00$ & $32.00 \pm 0.50$ & $40.00 \pm 0.00$ & $40.00 \pm 1.00$ & $30.00 \pm 0.00$ \\
\hline
\end{tabular}

${ }^{*}$ All the values are expressed as mean \pm standard error of mean $(\mathrm{n}=3)$. B. subtilis: Bacillus subtilis, S. aureus: Staphylococcus aureus, S. pyogenes: Streptococcus pyogenes, E. aerogenes: Enterobacter aerogenes, K. pneumonia: Klebsiella pneumoniae 
Table 4: MIC of different solvent extracts from Schefflera species

\begin{tabular}{|c|c|c|c|c|c|}
\hline \multirow[t]{2}{*}{ Extracts of Schefflera species } & \multicolumn{5}{|c|}{ MIC values of extracts (mg/ml) } \\
\hline & B. subtilis & S. aureus & S. pyogenes & E. aerogenes & K. pneumoniae \\
\hline S. venulosa leaf ethanol extract & 5.0 & $>10.0$ & $>10.0$ & $>10.0$ & $>10.0$ \\
\hline S. venulosa stem bark ethyl acetate extract & $>10.0$ & $>10.0$ & $>10.0$ & 5.0 & 5.0 \\
\hline S. racemosa leaf ethanol extract & 5.0 & $>10.0$ & 5.0 & $>10.0$ & $>10.0$ \\
\hline S. stellata leaf ethyl acetate extract & $>10.0$ & $>10.0$ & 5.0 & $>10.0$ & $>10.0$ \\
\hline S. stellata leaf ethanol extract & $>10.0$ & $>10.0$ & 5.0 & $>10.0$ & $>10.0$ \\
\hline Ciprofloxacin & 0.0012 & 0.0024 & 0.0049 & 0.0036 & 0.0195 \\
\hline
\end{tabular}

*All the values are expressed as mean \pm standard error of mean (n=3). MIC: Minimum inhibitory concentration, B. subtilis: Bacillus subtilis, S. aureus: Staphylococcus aureus, S. pyogenes: Streptococcus pyogenes, E. aerogenes: Enterobacter aerogenes, K. pneumoniae: Klebsiella pneumoniae, S. venulosa: Schefflera venulosa, S. racemosa: Schefflera racemosa, S. stellate: Schefflera stellata

The present study resulted in the antibacterial screening of 30 solvent extracts from four species of Schefflera, namely, S. venulosa, S. racemosa, and S. stellata. All three species studied showed positive results for antibacterial activity. Among the three plant species, S. venulosa, $S$. racemosa showed antibacterial activity against $B$. subtilis which is an encapsulated, Gram-positive, endospore-forming obligate aerobe, which causes food poisoning in immune-compromised patients. Of the various solvent extracts, the ethanol leaf and flower extract of $S$. venulosa, ethanol leaf extract of $S$. racemosa showed positive results against $B$. subtilis. The ethyl acetate stembark extract of $S$. venulosa, and ethanol leaf extract of $S$. racemosa showed positive results against E. aerogenes. E. aerogenes is a Gram-negative, rod-shaped bacteria which causes urinary infections and endocarditis among immunecompromised patients. Similarly, the ethyl acetate stem bark extract of $S$. venulosa showed positive results for K. pneumoniae a, facultative anaerobe which causes most of the nosocomial infections leading to morbidity and mortality. The ethyl acetate and ethanol leaf extract of S. stellata and ethanol leaf extract of $S$. racemosa showed potent activity against $S$. pyogenes.

At present, there is no evidence on the antimicrobial properties of $S$. venulosa and S. racemosa. However, the antimicrobial activity of S. stellata has been studied [18]. The volatile oils from the roots, stems, and leaves of $S$. stellata were responsible for the antifungal activity of leaf oil against Candida albicans and Candida glabrata by disc diffusion technique. Similarly, the methanolic leaf extracts of S. stellata showed a greater zone of inhibition $(11 \mathrm{~mm})$ when compared to all the tested organisms, followed by Xanthomonas axonopodis pv. malvacearum with a zone of $9 \mathrm{~mm}$ [23]. An inhibition zone of $7 \mathrm{~mm}$ was observed with S. aureus, Xanthomonas oryzae pv. Oryzae, and Salmonella Typhi strains. The antibacterial activity of $S$. stellata leaf extracts against six pathogenic bacteria was determined using a disc diffusion assay [24]. Different solvent extracts were used for the study, wherein the petroleum ether, chloroform, and the aqueous extract showed potent antibacterial activity against Escherichia coli $(3.5 \mathrm{~mm}$ zone of inhibition), Lactobacillus bacillus ( $6.0 \mathrm{~mm}$ zone of inhibition), and B. subtilis (4.0 mm zone of inhibition), respectively.

Of the 30 solvent extracts evaluated for the antibacterial activity, six extracts exhibited antibacterial activity (Tables 1-3). Among various solvent extracts from leaves and flower of $S$. venulosa, the ethanol extract showed a zone of inhibition against $B$. subtilis, whereas the ethyl acetate stem bark extract showed antibacterial activity against E. aerogenes and K. pneumoniae (Table 1). The ethanol leaf extracts of $S$. racemosa showed positive results against $B$. subtilis, $S$. pyogenes, and E. aerogenes (Table 3). Inhibitory activity against $S$. pyogenes was observed in the ethyl acetate and ethanol leaf extract of $S$. stellata (Table 3). The inhibition zone of methanol extract varied from $9.00 \pm 0.00 \mathrm{~mm}$ to $15.00 \pm 1.00 \mathrm{~mm}$ against both Gram-positive and Gramnegative bacteria. The MIC result obtained for the positive extracts of three Schefflera spp. strongly suggests that the extracts could be good antimicrobial agents (Table 4). Phytochemical investigations on these species indicated the presence of saponins, tannins, terpenoids, flavonoids, alkaloids, steroids, cardiac glycosides in the ethyl acetate, and methanolic extracts. The phytochemicals present in the plant species may be responsible for the antimicrobial activity of the extracts.

The non-polar solvent extracts demonstrated poor activity in all the organisms since no zones of inhibition were seen on the agar disc diffusion method. This is an indication that non-polar solvents were not good solvents, probably because the compounds responsible for bioactivity were not soluble in non-polar solvents such as hexane and chloroform [5]. In the present study, 30 solvent extracts of all the three species of Schefflera were screened for antibacterial activity and among them six solvent extracts showed potent antibacterial activity. This is the first report on the antibacterial activity of $S$. venulosa and S. racemosa extracts.

\section{CONCLUSION}

The present work is addressed on the antibacterial activities of three Schefflera species. The methanol extracts of Schefflera spp. showed a broad spectrum of activity against all the test organisms, employed. This may be attributed to the phytochemicals present in the plant species. Further, studies on the fractionation of the methanolic extracts and characterization by spectroscopy techniques may reveal the compounds responsible for the antibacterial potentials.

\section{ACKNOWLEDGMENT}

The authors thank the Chairman, Department of Studies in Botany, University of Mysore, for providing the research facilities to carry out the present study.

\section{AUTHORS' CONTRIBUTIONS}

The first author conducted the experimental parts involving solvent extractions of plant parts, screening for antibacterial activities, and the writing of the manuscript. The second author collected the plants S. venulosa, S. racemosa, and S. stellata from the Western Ghats and Chamundi Hills, respectively, and is involved in the overall presentation of the manuscript.

\section{CONFLICTS OF INTEREST}

The authors declare no conflicts of interest were involved in this study.

\section{FUNDING}

This work was supported from the financial assistance in the form of the Faculty Improvement Program (FIP) awarded to Mrs. Deepa R. Hebbar (No.FIP $/ 11^{\text {th }}$ plan/KAMY004 TF 08) by the University Grants Commission (UGC), Govt. of India.

\section{REFERENCES}

1. WHO. The Evolving Threat of Antimicrobial Resistance'-options for Actions; 2012. Available from: http://www.whqlibdoc.who.int/ publications/2012/9789241503181_eng.pdf. 
2. Jesumirhewe C, Umebuani DA, Ogunlowo PO. Multidrug resistance of Enterobacter aerogenes isolated from bovine animals in Okada, Edo state, Nigeria. Nova J Med Biol Sci 2014;3:1-5.

3. Manikandan C, Asmath A. Antibiotic susceptibility pattern of Klebsiella pneumoniae isolated from the urine sample. Int J Curr Microbiol Appl Sci 2013;2:330-7.

4. Sikarwar AS, Batra HV. Prevalance of antimicrobial drug resistance of Klebsiella pneumoniae in India. Int J Biosci Biochem Bioinform 2011;11:211-15.

5. Seanego CT, Ndip RN. Identification and antibacterial evaluation of bioactive compounds from Garcinia kola (Heckel) seeds. Molecules 2012;17:6569-84.

6. Bhunia AK. Food Borne Microbial Pathogens Mechanisms and Pathogenesis. United States of America: Springer Science+Business Media; 2008.

7. Vadlapudi V. In vitro antimicrobial activity of plant extracts of Avicennia alba against some important pathogens. Asian Pac J Trop Dis 2012;2:S408-11.

8. Parabia RM, Kathari IL, Parabia MH. Antibacterial activity of solvent fractions of crude water decoction of apical twigs of latex of Calotropis procera (Ait) R. Br. Indian J Natl Prod Resour 2008;7:30-34.

9. Cowan MM. Plant products as antimicrobial agents. Clin Microbiol Rev 1999;10:564-582.

10. Chandukishore T, Samskrathi D, Srujana TL. Examination of in vitro wound healing antimicrobial activity of extract of selected medicinal plants. Asian J Pharm Clin Res 2020;13:127-30.

11. Zerounal A, Elontassi N, Chaouch M, Chaqroune A. Antimicrobial, antioxidant and chemical composition of Origanum compactum Benth. From Taounate province, North Morocco. Asian J Pharm Clin Res 2020;13:126-31.

12. Davicino R, Mattar MA, Casali YA, Graciela S, Margerita E, Micalizzi B. Antifungal activity of plant extracts used in folk medicine in Argentina. Rev Peru Biol 2007; 14:247-51

13. Krishnamani R. A Comprehensive List of the Lianas of the Western Ghats of India-Version 2. The Rainforest Initiative, Coimbatore, India;
2015. Available from: http://www.rainforest-initiative.org/downloads/ pdfs/wghats_lianas_version_2.pdf.

14. Purohit MC, Pant $\bar{C}^{-}$, Rawat MS. Betulinic acid glycoside from S. venulosa. Phytochem 1991;30:2419.

15. Mohanan N, Sivadasan M. Flora of Agasthyamalai. Dehra Dun: Bishen Singh and Mahendra Pal Singh; 2002. p. 302

16. Rao JK, Reddy TV, Kumar OA. Ethnobotany of stem bark of certain plants of Visakhapatnam district, Andra Pradesh. Curr Bot 2011;2:1-6.

17. Kadavul K, Dixit AK. Ethnomedicinal studies of the woody species of Kalrayan and Shervarayan Hills, Eastern Ghats, Tamil Nadu. Indian J Tradit Know 2009;8:592-97.

18. Sabulal B, George V, Pradeep NS, Dan M. Volatile oils from the root, stem and leaves of S. stellata (Gaertn.) Harms. (Araliaceae): Chemical characterization and antimicrobial activity. J Essent Oil Res 2008;20:79-82

19. Deepa HR, Nalini MS. Phytochemical screening, total phenolic content and in vitro antioxidant studies of leaf, bark and flower extracts of Schefflera spp. (Araliaceae). J Appl Pharm Sci 2013;3:94-8.

20. Hebbar DR, Nalini MS. Evaluation of phytochemicals, total phenolics and antioxidant activities of Schefflera spp. (Araliaceae) from Southern India. J Pharmacogn Phytochem 2014;2:10-4.

21. Irobi ON, Moo-Young M, Anderson WA, Daramola SO. Antimicrobial activity of the bark of Bridelia ferruginea (Euphorbiaceae). Int $\mathrm{J}$ Pharmacogn 1994;34:87-90.

22. CLSI. Methods for Dilution Antimicrobial Susceptibility Tests for Bacteria that Grow Aerobically; Approved Standard. $10^{\text {th }}$ ed. Wayne, PA, USA: CLSI; 2015.

23. Aman M, Rai RV, Samaga PV. Antimicrobial and phytochemical screening of Boswellia serrata Roxb., Rhus mysorensis Heyne, Strychnos potatorum Linn. F. and Schefflera stellata Gaertn. Med Aromat Plant Sci Biotechnol 2010;4:69-72

24. Estari M, Supriya D. Antibacterial and phytochemical properties of Schefflera stellata (G.) leaf extracts against various bacterial species. Bull Pure Appl Sci Section A Zool 2012;31:65-71. 